\title{
Study on the Existing Problems and Their Countermeasures of the FDI Utilization in Jiangsu
}

\author{
Shuangqin Liu, Yingxue Mei \\ Business School of Hohai University, Nanjing, China \\ Email: Isqcarol@163.com
}

Received May 2014

\begin{abstract}
Jiangsu Province has convenient ocean, land and air transportation and great transportation capacity. There are 128 regular higher education institutions in Jiangsu, ranking the first by number in China. By the end of 2012, Jiangsu has a gross product of RMB5405.822 billion, accounting for $10.4 \%$ of the GDP of China as per Jiangsu Statistics Bureau (2013). According to the statistics of the National Bureau of Statistics of the People's Republic of China (2013), in 2012 in China, Jiangsu Province's economy ranked the second. With its advantages Jiangsu has attracted foreign direct investment (FDI) from all over the world. In 2012, there were 4156 contracted FDI projects. The contracted and the actually utilized FDI values reached US\$57.14109 billion and US\$35.75956 billion respectively. Not only has FDI brought capital, advanced technology, state-of-the-art management methods etc. for Jiangsu, but also it plays a very important role in Jiangsu's economic development. However, in Jiangsu's utilizing FDI some problems are existing, such as industries tending to be of the low end, imbalance in industry distribution, weak absorptive capacity of high technology, leading to environment pollution etc. This paper aims at analyzing the problems by SWOT method and puts forward some countermeasures for Jiangsu to develop its economy effectively by means of FDI.
\end{abstract}

\section{Keywords}

FDI Utilization, Jiangsu, Problems, Countermeasures

\section{Introduction}

Jiangsu Province is located to the east coast area of China with convenient ocean, land and air transportation. There are 128 regular higher education institutions in Jiangsu, ranking the first by number in China. As per Jiangsu Statistics Bureau (2013), by the end of 2012, Jiangsu has a total gross product of RMB5405.822 billion, accounting for $10.4 \%$ of the GDP of China. In China in 2012, Jiangsu Province's economy ranked the second. Because of the various advantages lots of foreign direct investment (FDI) from all over the world has been conducted in Jiangsu. 4156 FDI projects were contracted in Jiangsu in 2012. The contracted FDI and the actually 
utilized FDI values are US\$57.14109 billion and US\$35.75956 billion respectively. FDI has brought capital, advanced technologies, modern management methods etc. for Jiangsu, and plays an important part in Jiangsu's economic development. However, there are some problems existing in Jiangsu's utilizing FDI. This paper adopts SWOT method to analyze the problems and puts forward some countermeasures for Jiangsu to develop its economy effectively by using FDI.

\section{Literature Review}

De Mello thought that FDI can promote the economic development of the host countries by adding their new capitals based on the new economic growth theory [1].

Hill \& Athukorala emphasized that FDI can not only expand the export of the host countries and increase their abilities to improve their products and service, but also bring them tangible and intangible resources such as capital, R \& D, knowledge, technology, managing experiences etc. [2].

Kumer pointed out that the effects that FDI projects bring to the host countries depend on the new knowledge and its diffusing scope in the economy FDI brings, the new overseas market for the manufactured products brought by FDI, the contribution to establishing technical competence by FDI, etc. [3].

According to Sang Baichuan, China should continue to use FDI, which can add capital supply, promote economic growth, increase employment and tax revenue, and change social and economic conditions [4].

Matar analyzed the absorptive capacity of FDI in Arabian countries and found that Arabian countries have learnt high supervision quality [5].

Johnson's research shows that the inflow in developing countries has promoted their economic growth, but not in developed countries [6].

Zu Qiang et al. studied the relations between FDI and the economic growth in Jiangsu [7]. Hao Sijun et al. analyzed how FDI affects the economic development of Jiangsu [8]. Wan Li et al. studied how FDI is used in the agriculture of Jiangsu [9]. And Bu Shengjuan analyzed how FDI influenced the environment quality of Jiangsu [10].

The above researches are conduced from a certain perspective. This paper mainly discusses how Jiangsu should effectively take advantage of FDI and make it promote the economic development of Jiangsu.

\section{SW0T Analysis}

Based on the researches on FDI, SWOT method is adopted to analyze the FDI utilization in Jiangsu as shown in Figure 1.

\section{The Existing Problems of FDI Utilization in Jiangsu}

On the basis of the above analysis and integrating with Table 1, it can be found that the problems existing in the FDI utilization of Jiangsu are as follows.

\subsection{Industries Tending to Be of the Low End}

FDI utilization of Jiangsu mainly focuses on secondary industry, which is of low class, and most of which are labor-intensive and thus cannot promote the updating or optimization of the industry structure. There are few FDI enterprises with high technology. The industry cluster level and utilizing rate of high technology are not high enough. FDI is focused excessively on the mature industries.

\subsection{Imbalance in FDI Industry Distribution}

It can be seen from Table 1 that FDI in Jiangsu is mainly on manufacturing, such as textile, clothing, shoe, cap making, metal ware industries, etc. FDI in agriculture, forest, herd and fishing industries is more than before but still very low compared with manufacturing. Therefore, FDI in the industry distribution is not reasonable.

\subsection{Imbalance in FDI Region Distribution}

The south part of Jiangsu is near Shanghai with good infrastructure conditions and economic technology bases, thus attracting many multinational companies and resulting in cluster effect. While the north and middle parts of 


\begin{tabular}{|c|c|c|}
\hline & $\begin{array}{l}\text { Strengths } \\
\text { 1. Near the coast and Shanghai } \\
\text { 2. Convenient transportation with strong transit } \\
\text { capacities } \\
\text { 3. Developed economy compared with other } \\
\text { provinces in China } \\
\text { 4. Having the most universities in China and high } \\
\text { level personnel } \\
\text { 5. Good infrastructure } \\
\text { 6. High urbanization and high opening level of } \\
\text { trade } \\
\text { 7. Huge market }\end{array}$ & $\begin{array}{l}\text { Weaknesses } \\
\text { 1. A large population and lacking } \\
\text { land resource } \\
\text { 2. Increasing labor cost } \\
\text { 3. Imperfect relative policies and } \\
\text { laws } \\
\text { 4. Large differences between } \\
\text { regions } \\
\text { 5. Not high management level of } \\
\text { FDI }\end{array}$ \\
\hline & $\begin{array}{l}\text { Opportunities } \\
\text { 1. China's opening policy } \\
\text { 2. Adding capitals } \\
\text { 3. Getting technology transfer and promoting } \\
\text { technology upgrading } \\
\text { 4. Promoting industry structure adjustment } \\
\text { 5. Promoting international trade and expanding } \\
\text { foreign exchange and cooperation } \\
\text { 6. Promoting economic growth and increasing } \\
\text { productivity } \\
\text { 7. Increasing employment } \\
\text { 8. Bringing advanced operation concepts, } \\
\text { management methods and marketing } \\
\text { techniques }\end{array}$ & $\begin{array}{l}\text { Threats } \\
\text { 1. World financial and economic } \\
\text { crises } \\
\text { 2. Change in exchange rate and } \\
\text { appreciation in Chinese currency } \\
\text { 3. Competition from other } \\
\text { countries and regions } \\
\text { 4. Competing domestic market } \\
\text { share } \\
\text { 5. Original favorable policies are } \\
\text { not attractive } \\
\text { 6. Withdrawal of FDI because of } \\
\text { strategic adjustment }\end{array}$ \\
\hline
\end{tabular}

Figure 1. SWOT Analysis of FDI Utilization in Jiangsu.

Table 1. FDI Utilization by Industries with over 100 Projects (2012) Unit: US\$10,000.

\begin{tabular}{|c|c|c|c|}
\hline Industry & Project & Contracted FDI & Actually Utilized FDI \\
\hline Total & 4156 & $5,714,109$ & 3,575,956 \\
\hline Agriculture, forest, herd and fishing & 282 & 274,033 & 148,365 \\
\hline Manufacturing & 2246 & $3,759,928$ & $2,232,844$ \\
\hline Textile, clothing, shoe, cap making & 190 & 146,701 & 94,034 \\
\hline Metal ware making & 112 & 204,083 & 102,202 \\
\hline General equipment making & 444 & 668,949 & 320,504 \\
\hline Special equipment making & 238 & 337,113 & 174,091 \\
\hline Transportation equipment making & 157 & 383,211 & 229,967 \\
\hline Electrical machinery and equipment making & 245 & 520,077 & 290,337 \\
\hline $\begin{array}{l}\text { Communication apparatus, computers and } \\
\text { other electrical equipment making }\end{array}$ & 276 & 435,418 & 247,752 \\
\hline Information transmission, computer and software & 182 & 77,052 & 27,212 \\
\hline Wholesale and retail & 627 & 333,207 & 174,639 \\
\hline Leasing and business service & 236 & 234,658 & 111,921 \\
\hline $\begin{array}{l}\text { Scientific research, technical service } \\
\text { and geological exploration }\end{array}$ & 178 & 52,400 & 37,013 \\
\hline
\end{tabular}


Jiangsu cannot attract much FDI compared with the south part, due to thinking, concepts, economic base, local environments, insufficient opening level and so on, thus resulting in a large gap between the north and middle parts and the south part.

\subsection{Weak Absorptive Capacity of High Technology}

In the FDI in high tech industries, multinational companies don't disclose their technology, so enterprises in Jiangsu are unable to learn their core technology, making them unable to absorb or learn advanced technology by means of joint ventures, unable to increase their R \& D competences, especially competences in high-tech products including communications equipment, computers and office equipment. The profitability is limited because of lacking the core technology. Besides, some key technology has to depend on foreign companies.

\subsection{Leading to Environment Pollution}

That FDI is not used effectively is attributed to the investing in the industries with high energy consumption and high pollution of FDI, thus further aggravating resource shortage and environment pollution. And the resource shortage and environment pollution will adversely affect FDI.

\section{Countermeasures}

\subsection{Widening FDI Fields}

FDI utilization in Jiangsu focuses on manufacturing, so FDI in the secondary industry especially processing industry and labor intensive industries should be controlled, and FDI should be led to new agricultural technology and comprehensive land resource development, moving gradually from manufacturing to the capital and technology intensive industries such as equipment making, service, infrastructure, and high tech industries. Integrating FDI use with increasing industry structure and technology level, regarding the structure optimization as the basic standard of FDI, FDI should be led to the tertiary industry from secondary industry by means of policies.

\subsection{Optimizing FDI Structure}

In the FDI utilization in Jiangsu, there is an increase in agriculture and service, but with the expanding of the quantity and the scope of FDI, the structure of FDI is found more and more unreasonable. Related policies should be made to adjust the FDI strategy, i.e. transferring from the present manufacturing to the tertiary industry gradually. The opening level of the service should be expanded, and FDI should be led to communication, tourism, environment protection, finance, trade, consulting, accounting, lawyer, information, advertising etc.

\subsection{Bridging the Gap between the South Part and the Middle and North Parts}

In the south part, the economic development level and opening degree are relatively higher. While in the middle and the north parts, the economic development level and opening degree are lagging behind. Therefore, some policies should be made to support the middle and the north parts. More effective policies should be made by the middle and the north parts to widen their FDI fields, improve their investing environment, and industry matching conditions. And the south part should continue to put FDI in high tech industries. All the three parts should cooperate, coordinate and develop together, complement each other, and move FDI from the south to the middle and north parts gradually.

\subsection{Increasing Investment in $\mathrm{R} \& \mathrm{D}$ and Training $\mathrm{R} \& \mathrm{D}$ Personnel}

With the advantage of high level personnel, Jiangsu should encourage foreign companies to establish R \& D institutions in Jiangsu. By means of doing so, Jiangsu can benefit more directly and obtain advanced technology. In the meantime, Jiangsu should invest more in R \& D to train R \& D personnel and improve R \& D and innovative competences.

\subsection{Making Policies to Protect Environment}

While using FDI, Jiangsu should strengthen to supervise the environment of the foreign enterprises, in particular, 
the ones of manufacturing. Those enterprises of high energy consumption and high discharge should be controlled. On the other hand, those enterprises of high tech, with high tech contents, should be encouraged in order to develop the economy without damaging the environment quality.

\subsection{Emphasizing the Quality but Not the Quantity of FDI}

Based on scientific development laws, FDI in the mature industries should be restricted. Those with high tech contents should be encouraged so as to maximize the profit of FDI use. The resource cluster, output effect and environment effect should be used as the standards to use FDI and thus increase the sustainable development capacity.

\section{Conclusion}

SWOT method is adopted to analyze FDI utilization in Jiangsu Province. The findings show that the FDI in Jiangsu should be led to the high tech industries gradually in order to make FDI promote the economic development of Jiangsu effectively.

\section{References}

[1] De Mello Jr., L.R. (1997) Foreign Direct Investment in Developing Countries and Growth: A Selective Survey. The Journal of Development Studies, 34, 1-34. http://dx.doi.org/10.1080/00220389708422501

[2] Hill, H. and Athukorala, P. (1998) Foreign Investment in Asian: A Survey. Asian-Pacific Economic Literature, 12, 2350 .

[3] Kumar, N. (2002) Globalization and the Quality of Foreign Direct Investment. Oxford University Press, New Delhi.

[4] Sang, B.C. (2004) Why Does China Need to Use FDI Actively? International Economic Cooperation, 11.

[5] Krogstrup, S. and Matar, L. (2005) Foreign Direct Investment, Absorptive Capacity and Growth in the Arab World. Graduate Institute of International Studies, Geneva.

[6] Johnson, A. (2006) The Effects of FDI Inflows on Host Country Economic Growth. CESIS Working Paper Series, Paper No.58, Royal Institute of Technology, Sweden.

[7] Zu, Q. and Zhou Z.Y. (2008) Relations between FDI and Jiangsu's Economic Growth. Economic Study, 4, 50-53.

[8] Hao, S.J., Gu, Y.P. and Dong, P. (2010) Analysis on the Effects of FDI on Jiangsu Economic Development, Statistics Science and Practice, 12, 22-24.

[9] Wan, L. and Zang, X. (2010) The Present Situation, Problems and Suggestions of FDI Use in Jiangsu's Agriculture, Journal of Jiangsu Institute of Education (Social Science), 1, 102-104.

[10] Bu, S.J. (2012) Study on the Effect on the Environment Quality of FDI in Jiangsu. Journal of Zhengzhou Institute of Aeronautical Industry Management, 11, 70-73. 